Jurnal Keuangan dan Perbankan, 23(3): 321 - 334, 2019

http://jurnal.unmer.ac.id/index.php/jkdp

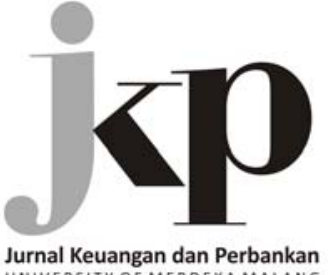

UNIVERSITY OF MERDEKA MALANG

Article history:

Received: 2019-04-11

Revised: 2019-05-25

Accepted: 2019-07-02

Keywords:

Aggressive investing;

Performance; Resource based

view; Strategy

JEL Classification: C23, D21, G31, L25

Kata kunci:

Investasi agresif; Kinerja; Resource based view; Strategi

$\triangle$ Corresponding Author:

Rayenda Khresna Brahmana:

Tel. +60 82584488

E-mail: raye_brahm@yahoo.com

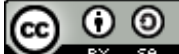

This is an open access

article under the CC-BY-SA license

\section{Has aggressive investing strategy performed? An insight from Malaysia listed companies}

\author{
Maria Kontesa ${ }^{1}$, Emily Jia Chee Lim $^{2}$, Rayenda Khresna Brahmana ${ }^{2}$ \\ ${ }^{1}$ Department of Accounting, STIE Widya Dharma Pontianak \\ Jl. Hos Cokroaminoto No.16, Pontianak, 78243, Indonesia \\ ${ }^{2}$ Department of Accounting and Finance, Faculty of Economics and Business, Universiti \\ Malaysia Sarawak \\ Jl. Datuk Mohammad Musa, Sarawak, 94300, Malaysia
}

\section{Abstract}

This study examines the role of aggressive investing strategy on firm performance for a sample of 514 listed firms in Malaysia from 2010 to 2017. In our first objective, we investigate the investing activism effect on firm performance by simultaneously controlling the firm characteristics and industry in our model. Our second objective is to test whether aggressive investing activism affects the firm performance. Lastly, we want to investigate whether this aggressive investing may produce different result with different measures of performance. Our findings show that investment has significant effects on firm performance. Our research further indicates that companies with aggressive investing strategies had a better firm performance than compared to its peers. We test this theory using three different measures of aggressive investing strategies and substantiate this conclusion. Our research confirms the resource based view theory and empirically proves that aggressive investments would result in better firm performance.

\section{Abstrak}

Studi ini menguji peran strategi investasi agresif pada kinerja perusahaan untuk sampel 514 perusahaan yang terdaftar di Malaysia dari 2010 hingga 2017. Dalam tujuan pertama kami, kami meneliti pengaruh aktivitas investasi terhadap kinerja perusahaan secara simultan dengan kontrol karakteristik perusahaan dan industri dalam model penelitian kami. Tujuan kedua kami adalah untuk menguji apakah aktivitas investasi agresif memengaruhi kinerja perusahaan. Terakhir, kami ingin menyelidiki apakah investasi agresif ini dapat menghasilkan hasil yang berbeda dengan ukuran kinerja yang berbeda. Temuan kami menunjukkan bahwa investasi memiliki pengaruh signifikan terhadap kinerja perusahaan. Lebih lanjut penelitian kami menunjukkan bahwa perusahaan dengan strategi investasi yang agresif memiliki kinerja perusahaan yang lebih baik dibandingkan dengan perusahaan sejenisnya. Kami menguji teori ini menggunakan tiga ukuran strategi investasi agresif yang berbeda dan mendukung kesimpulan ini. Penelitian kami menegaskan teori resource based view dan membuktikan secara empiris bahwa investasi yang agresif akan menghasilkan kinerja perusahaan yang lebih baik.

How to Cite: Kontesa, M., Lim, E. J. C., \& Brahmana, R. K. (2019). Has aggressive investing strategy performed? An insight from Malaysia listed companies. Jurnal Keuangan dan Perbankan, 23(3), 321-334.

https://doi.org/10.26905/jkdp.v23i3.3069 